\title{
Quinoa and Flaxseed: Potential Ingredients in the Production of Bread with Functional Quality
}

\author{
Valéria Alcântara Santos Calderelli ${ }^{1}$, Marta de Toledo Benassi ${ }^{2}$, Jesuí Vergílio Visentainer ${ }^{3}$ \\ and Graciette Matioli ${ }^{4 *}$ \\ ${ }^{I}$ Centro de Ciências da Saúde; Universidade Estadual de Maringá; Maringá - PR - Brasil. ${ }^{2}$ Departamento de \\ Ciência e Tecnologia de Alimentos; Universidade Estadual de Londrina; Londrina - PR - Brasil. ${ }^{3}$ Departamento de \\ Química; Universidade Estadual de Maringá; Maringá - PR - Brasil. ${ }^{4}$ Departamento de Farmácia e Farmacologia; \\ Universidade Estadual de Maringá; Av. Colombo, 5790; 87020-900; Maringá - PR - Brasil
}

\begin{abstract}
The objective of this work was to compare the physicochemical characteristics of quinoa and flaxseed bread. Sensory acceptance, color and texture were also appraised. They showed appropriate balances between their content of polyunsaturated and saturated fatty acids and low levels of trans fatty acids. Flaxseed bread had larger amounts of mono and polyunsaturated fatty acids, omega-6 and omega-3, as well as a more balanced omega6/omega-3 ratio. Quinoa bread, on the other hand, had the advantage of presenting smaller contents of saturated fatty acids. With regard to color and texture, quinoa bread had similar characteristics to the flaxseed bread. The quinoa bread was well accepted by the consumers, who expressed high interest in buying it.
\end{abstract}

Key words: fatty acids; Chenopodium quinoa; Linum usitatissimum; functional food

\section{INTRODUCTION}

Functional foods are defined as any substance or component of a food that offers health benefits, including in the prevention and treatment of diseases. The main functional components of foods are fibers, polyunsaturated fatty acids, phytochemicals, active peptides, prebiotics and probiotics (Kucuk, 2002). The human body synthesizes the majority of saturated and unsaturated fatty acids, although not the essential ones: omega-3 (linolenic acid) and omega-6 (linoleic acid) (Soccol and Oetterer, 2003). They are found in cold-water fish, vegetable oils, flaxseed, quinoa, nuts and some vegetables (Kris Etherton et al., 2002).
Flax (Linum usitatissimum; Linaceae), also known as linseed, is a plant that is cultivated primarily for the use of its seeds and fiber. It has a dark brown seed that is used in the food industry as a complement in the preparation of bread and cakes. Its level of omega-3 fatty acid, around 60\%, makes the seed the greatest vegetarian source of this compound. The omega- 6 fatty acid is also present in its seeds (Cunnane et al., 1993; Hall III et al., 2005). The consumption of flaxseed, which is an ingredient that is already known and consumed, provides appropriate levels of polyunsaturated fatty acids, and has an important role in the prevention and regulation of cardiac and autoimmune diseases, breast, prostate and colon

*Author for correspondence: gmatioli@uem.br 
cancer, and rheumatoid arthritis (Jump, 2002; Kris-Etherton et al., 2002; Choo et al., 2007).

Quinoa (Chenopodium quinoa Willd.), a Chenopodiaceae originating from the Andes, is distinguished as being a cereal with high-quality protein and absence of gluten (Spehar and Santos, 2002). It has high levels of essential fatty acids, with good oxidative stability and, therefore, the potential to be used as an alternative culture in oil production ( $\mathrm{Ng}$ et al., 2007). While quinoa is not used in the diet of most people, it is currently used as a substitute for wheat flour in the production of bread for celiac consumers, with substitutions in small amounts having shown a positive effect on the quality of the breads (Park et al., 2005).

Considering the potential of quinoa and flaxseed with regard to the consumption of omega- 3 and omega-6 fatty acids, which have been widely used as functional ingredients, the present study had the objective of comparing the characteristics of a new type of bread containing quinoa to flaxseed bread.

\section{MATERIALS AND METHODS}

\section{Production of the bread}

The breads with powdered flaxseed (Linhaça Jasmine, Curitiba-Brazil) and the quinoa grains (Quinua, São Paulo-Brazil), was made in an industrial food mixer (Perfecta model RS-20, Curitiba-Brazil). The dough was prepared by combining the following dry ingredients: sugar (3 $\mathrm{g})$, salt $(0.7 \mathrm{~g})$, benzoic acid $(0.2 \mathrm{~g})$, strengthener $(0.5 \mathrm{~g})$, wheat flour $(47 \mathrm{~g})$, wheat fiber $(4 \mathrm{~g})$, soya oil $(4 \mathrm{~g})$ and powdered flaxseed $(6 \mathrm{~g})$ or quinoa grains $(6 \mathrm{~g})$. Yeast $(4 \mathrm{~g})$ was then added, followed by water $(27 \mathrm{~g})$. After shaping, the breads were baked in oven (Perfecta model Modulare, CuritibaBrazil) at $170^{\circ} \mathrm{C} / 30 \mathrm{~min}$, cooled to room temperature and sliced in an industrial bread slicer (Perfecta, Model RDS-09, Curitiba-Brazil). The breads were then packed in plastic bags.

\section{Physicochemical characterization}

The analyses of the moisture, ash and raw protein contents were carried out according to AOAC (Cunniff, 1998). For protein analysis, the factor of 6.25 was used. Total lipids was determined according to Bligh and Dyer (1959), using a methanol: chloroform: water ratio of 2:2:1.8 $(\mathrm{v} / \mathrm{v} / \mathrm{v})$, respectively. Fiber and mineral content were analyzed according to Instituto Adolfo Lutz (2005). All analyses were carried out in triplicate.
The transesterification of fatty acids was carried out according to Sanches et al. (1997) and Martin et al. (2005). Using a gas chromatograph (Varian, model AA 3380) with a flame ionization detector and a GC fused-silicon capillary column (Select FAME-CP-7420) $(100 \mathrm{mx} \quad 0.25 \mathrm{~mm}, 0.25 \mu \mathrm{m}$, cyanopropyl). Hydrogen was used as carrier gas $\left(1.0 \mathrm{~mL} \mathrm{~min}^{-1}\right)$ and nitrogen $\left(30 \mathrm{~mL} \mathrm{~min}{ }^{-1}\right)$ as auxiliary gas. Flame gases were hydrogen $(30 \mathrm{~mL}$ $\left.\mathrm{min}^{-1}\right)$ and synthetic air $\left(300 \mathrm{~mL} \min ^{-1}\right)$. The injected volume was $1.0 \mu \mathrm{L}$, using a 1:80 split ratio, with the temperatures of the injector and the detector being 220 and $240^{\circ} \mathrm{C}$, respectively, while temperature of the column was $165^{\circ} \mathrm{C}$ for $18 \mathrm{~min}$, which was raised to $235^{\circ} \mathrm{C}$ at a rate of $4^{\circ} \mathrm{C} / \mathrm{min}$, and maintained for $25 \mathrm{~min}$. The identification was carried out by comparison with retention time of standards, with ECL (Equivalent Chain Length) values and spiking. The results were expressed as $\mathrm{mg}$ of fatty acid/g of total lipids. Tricosanoic acid methyl ester, as internal standard, and fatty acid methyl esters (Sigma) of 99\% purity were used. The analyses were carried out in triplicate.

The determination of color and texture was carried out on the crust and crumb of the bread. A Minolta CR10 colorimeter (Konica Minolta Inc., NJ, USA), with CIE D 65 illuminant and a $10^{\circ}$ standard CIE observer was used. Lightness, redgreen and yellow-blue components $\left(\mathrm{L}^{*}, \mathrm{a}^{*}, \mathrm{~b}^{*}\right)$ were measured, with ten repetitions for each analysis. A TA-XT2 texturometer (Stable Micro Systems, Surrey, England) was used following the AACC method (74-09) (ABI, 2007). Using a cylindrical acrylic probe with a diameter of one inch, distance of $10.0 \mathrm{~mm}$ and force of $0.10 \mathrm{~N}$. Two slices of bread were used for each compression, and ten analysis were carried out for each sample for the determination of firmness $(\mathrm{N})$. All the experiments were carried out in a completely randomized design. The results were submitted to analysis of variance (ANOVA), with the type of bread (flaxseed or quinoa) as the source of variance, and Tukey means tests $(5 \%$ significance level), using the software Statistica 6.0/2001 (Statsoft, Inc. Tulsa, USA).

\section{Sensory analysis}

To find out the acceptance of the quinoa bread, a central location test was carried out in local bakery between 16:00 and 19:30h. One hundred and three potential consumers were used for the sensory analysis. They were routine clients of the bakery, the majority (74\%) of whom already had the habit 
of consuming bread with functional properties (e.g. wholemeal flaxseed, flour or cereal bread). Fifty eight percent consumed the bread from 1 to 7 times a week and $44 \%$ consumed it at least 1 or 2 times a month. The first three slices of the ends of the bread were not used, and the remaining slices $(20 \mathrm{~g})$ were cut into four equal parts and offered to the customers. A seven-point hedonic scale anchored with verbal terms at the ends and in the middle was used. Purchase intention for the product, the reason for intending to buy/not to buy it and consumption frequency for bread made from ingredients with functional properties were asked.

\section{RESULTS AND DISCUSSION}

The two types of breads showed significant differences for the majority of the parameters studied, with the flaxseed bread being characterized by a greater content of lipids. The flaxseed bread also had a greater caloric value, although this difference was less than $10 \%$ (Table 1). The fatty acid compositions of raw flaxseed and quinoa, the soya oil used, and the flaxseed and quinoa breads are presented in Table 2 .

The two types of bread presented low levels of trans fatty acids (around 0,5\%). The flaxseed bread had higher levels of saturated, monounsaturated, polyunsaturated, omega- 6 and omega- 3 fatty acids. The levels of saturated fatty acids in the quinoa bread were low enough for it to be labeled as having "low levels of saturated fatty acids" in
Brazil. The label is used for the products with saturated fatty acid levels of a maximum of $1.5 \mathrm{~g}$ of saturated fat per $100 \mathrm{~g}$ (solids) (Brasil, 1998).

Some studies have recommend that, in order to be considered healthy with regard to cardiac diseases, the ratio between the sum of the omega- 6 and omega-3 fatty acids should be a maximum of 4 , and the ratio between the sum of the polyunsaturated and saturated fatty acids should be more than 0.45 (Department of Health, 1994). The flaxseed bread was within the above-mentioned limits. However, the quinoa bread satisfied only the recommendation about the ratio between the sums of the polyunsaturated and saturated fatty acids. Choo et al. (2007) analyzed the fatty acid compositions of seven flaxseed oils obtained by cold pressing and commercially sold in New Zealand. The mean ratio between the sums of the omega- 6 and omega- 3 fatty acids obtained for the oils was 0.28 , and for the polyunsaturated and saturated fatty acids was 7.7 , therefore being in line with the suggested parameters. These differences were probably due to the different origins of the raw materials and to the possibility of losses during the process of obtaining the oil from the seeds, even when the cold pressing process was used.

The nutritional value per portion of each sample and the recommended daily allowance (RDA \%), based on 2000 calories/day, according to brazilian legislation on nutritional labeling (Brasil, 2003), can be seen in table 3 .

Table 1 -Wet-weight percentage composition and calorific value of flaxseed bread and quinoa bread ${ }^{(1)}$.

\begin{tabular}{lcc}
\hline Components & Flaxseed bread $^{(2)}$ & Quinoa bread $^{(2)}$ \\
\hline Moisture (\%) & $32.76 \pm 0.06^{\mathrm{a}}$ & $30.95 \pm 0.02^{\mathrm{b}}$ \\
Lipids (\%) & $8.81 \pm 0.06^{\mathrm{a}}$ & $5.25 \pm 0.02^{\mathrm{b}}$ \\
Raw Protein (\%) & $8.56 \pm 0.02^{\mathrm{a}}$ & $8.23 \pm 0.00^{\mathrm{b}}$ \\
Fiber $(\%)$ & $2.01 \pm 0.01^{\mathrm{a}}$ & $1.20 \pm 2.10^{\mathrm{b}}$ \\
Mineral residue $(\%)$ & $1.61 \pm 0.00^{\mathrm{a}}$ & $1.54 \pm 0.01^{\mathrm{b}}$ \\
Sodium $(\% \mathrm{mg} / 100 \mathrm{~g})$ & $316.78 \pm 0.16^{\mathrm{a}}$ & $303.18 \pm 0.05^{\mathrm{b}}$ \\
Calories $(\mathrm{kJ} / 100 \mathrm{~g})$ & $1251 \pm 0.60^{\mathrm{b}}(299 \mathrm{kcal} / 100 \mathrm{~g})$ & $1217 \pm 0.64^{\mathrm{a}}(291 \mathrm{kcal} / 100 \mathrm{~g})$ \\
\hline
\end{tabular}

${ }^{(1)}$ Means of three analytical repetitions \pm standard deviation.

${ }^{(2)}$ Different letters in the line indicate statistically significant differences between samples $(\mathrm{p} \leq 0.05)$ 
Table 2 - Fatty acid compositions in raw flaxseed and quinoa (in percentages), and of flaxseed and quinoa bread (in grams per $100 \mathrm{~g}$ of product) ${ }^{(1)}$.

\begin{tabular}{|c|c|c|c|c|c|}
\hline Fatty acids & Raw flaxseed & Raw quinoa & Soya oil & Flaxseed Bread $^{(2)}$ & Quinoa bread $^{(2)}$ \\
\hline C14:0 & $0.05 \pm 0.01$ & $0.17 \pm 0.00$ & $0.09 \pm 0.00$ & ND & $0.01 \pm 0.01$ \\
\hline C16:0 & $6.41 \pm 0.07$ & $9.82 \pm 0.31$ & $10.72 \pm 0.11$ & $0.95 \pm 0.36^{\mathrm{a}}$ & $0.57 \pm 0.62^{b}$ \\
\hline $\mathrm{C} 16: \ln 7$ & $0.07 \pm 0.00$ & ND & $0.09 \pm 0.00$ & $0.02 \pm 0.04^{\mathrm{a}}$ & $0.01 \pm 0.01^{\mathrm{a}}$ \\
\hline $\mathrm{C} 17: 0$ & $0.05 \pm 0.00$ & ND & $0.07 \pm 0.00$ & ND & $0.004 \pm 0.00$ \\
\hline $\mathrm{C} 17: \ln 7$ & $0.03 \pm 0$ & ND & $0.00 \pm 0.01$ & ND & ND \\
\hline C18:0 & $4.39 \pm 0.06$ & $1.47 \pm 0.01$ & $3.78 \pm 0.05$ & $0.44 \pm 0.25^{\mathrm{a}}$ & $0.23 \pm 0.28^{\mathrm{b}}$ \\
\hline $\mathrm{C} 18: 19 \mathrm{t}$ & ND & ND & $0.10 \pm 0.01$ & $0.54 \pm 0.82^{\mathrm{a}}$ & $0.31 \pm 0.52^{\mathrm{b}}$ \\
\hline C18:1n9 & $18.21 \pm 0.01$ & $29.90 \pm 0.14$ & $26.60 \pm 0.25$ & $2.12 \pm 1.04^{\mathrm{a}}$ & $1.20 \pm 1.07^{\mathrm{b}}$ \\
\hline C18:1n7 & $0.28 \pm 0$ & ND & $1.19 \pm 0.01$ & $0.08 \pm 0.04^{\mathrm{a}}$ & $0.05 \pm 0.06^{\mathrm{b}}$ \\
\hline $\mathrm{C} 18: 29 \mathrm{c}, 12 \mathrm{t}$ & ND & ND & $0.22 \pm 0.00$ & $0.02 \pm 0.03^{\mathrm{a}}$ & $0.01 \pm 0.01^{\mathrm{b}}$ \\
\hline $\mathrm{C} 18: 29 \mathrm{t}, 12 \mathrm{c}$ & ND & ND & $0.17 \pm 0.00$ & $0.02 \pm 0.02^{\mathrm{a}}$ & $0.01 \pm 0.01^{\mathrm{b}}$ \\
\hline $\mathrm{C} 18: 2 \mathrm{n} 6$ & $13.17 \pm 0.04$ & $48.8 \pm 0.41$ & $49.89 \pm 0.46$ & $2.98 \pm 0.71^{\mathrm{a}}$ & $1.91 \pm 1.57^{\mathrm{b}}$ \\
\hline C18:3n6 & $0.19 \pm 0.01$ & ND & $0.31 \pm 0.00$ & $0.02 \pm 0.00^{\mathrm{a}}$ & $0.01 \pm 0.01^{\mathrm{b}}$ \\
\hline C20:0 & $0.15 \pm 0.01$ & $0.33 \pm 0.01$ & $0.72 \pm 0.00$ & $0.05 \pm 0.01^{\mathrm{a}}$ & $0.03 \pm 0.02^{\mathrm{b}}$ \\
\hline $\mathrm{C} 18: 3 \mathrm{n} 3$ & $56.63 \pm 0.03$ & $7.34 \pm 0.19$ & $4.56 \pm 0.05$ & $1.24 \pm 0.34^{\mathrm{a}}$ & $0.16 \pm 0.14^{\mathrm{b}}$ \\
\hline C20:1n9 & $0.10 \pm 0.02$ & $1.53 \pm 0.07$ & $0.25 \pm 0.03$ & $0.02 \pm 0.01^{\mathrm{a}}$ & $0.01 \pm 0.01^{\mathrm{b}}$ \\
\hline $\mathrm{C} 22: 0$ & $0.13 \pm 0.01$ & $0.58 \pm 0.04$ & $0.53 \pm 0.01$ & $0.06 \pm 0.03^{\mathrm{a}}$ & $0.02 \pm 0.02^{\mathrm{b}}$ \\
\hline $\mathrm{C} 24: 0$ & $0.09 \pm 0.01$ & ND & $0.19 \pm 0.00$ & $0.04 \pm 0.01^{\mathrm{a}}$ & $0.008 \pm 0.01^{\mathrm{b}}$ \\
\hline Saturated & $11.28 \pm 0.02$ & $12.4 \pm 0.39$ & $15.75 \pm 0.38$ & $1.54 \pm 0.08^{\mathrm{a}}$ & $0.87 \pm 0.12^{\mathrm{b}}$ \\
\hline Monounsaturated & $18.02 \pm 0.01$ & $31.44 \pm 0.21$ & $27.89 \pm 0.28$ & $2.22 \pm 0.14^{\mathrm{a}}$ & $1.27 \pm 0.14^{\mathrm{b}}$ \\
\hline Polyunsaturated & $69.99 \pm 0.03$ & $56.14 \pm 0.6$ & $54.61 \pm 0.37$ & $4.23 \pm 0.12^{\mathrm{a}}$ & $2.08 \pm 0.21^{\mathrm{b}}$ \\
\hline Trans & ND & ND & $0.51 \pm 0.05$ & $0.58 \pm 0.10^{\mathrm{a}}$ & $0.34 \pm 0.07^{\mathrm{b}}$ \\
\hline Omega-6 & $13.36 \pm 0.05$ & $48.8 \pm 0.41$ & $49.69 \pm 0.33$ & $3.00 \pm 0.09^{\mathrm{a}}$ & $1.92 \pm 0.19^{\mathrm{b}}$ \\
\hline Omega-3 & $56.63 \pm 0.03$ & $7.34 \pm 0.19$ & $4.52 \pm 0.04$ & $1.23 \pm 0.04^{\mathrm{a}}$ & $0.16 \pm 0.02^{b}$ \\
\hline Omega-6/omega-3 & 0.24 & 6.62 & 10.99 & $2.43^{b}$ & $12^{\mathrm{a}}$ \\
\hline Polyunsat./saturated & 6.20 & 4.52 & 3.46 & $2.85^{\mathrm{a}}$ & $2.40^{\mathrm{b}}$ \\
\hline
\end{tabular}

${ }^{(1)}$ Means of three analytical repetitions \pm standard deviation.

${ }^{(2)}$ Different letters in the same line indicate statistically significant differences among samples $(\mathrm{p} \leq 0.05)$.

$\mathrm{ND}=$ Not detected .

Table 3 - Nutritional value per portion of each sample and the recommended daily allowance (RDA\%), based on 2000 calories/day $^{(1)}$.

\begin{tabular}{ccccc}
\hline Components & $\begin{array}{c}\text { Flaxseed bread } \\
\text { 50 g portion (2 slices) }\end{array}$ & RDA (\%) & $\begin{array}{c}\text { Quinoa bread } \\
\text { 50 g portion (2 slices) }\end{array}$ & RDA (\%) \\
\hline Calories (kcal) & 150 & 8 & 150 & 8 \\
Carbohydrates (g) & 23 & 8 & 26 & 9 \\
Proteins (g) & 4.3 & 6 & 4 & 5 \\
Total fatty acids (g) & 4.4 & 8 & 3 & 5 \\
Omega-6 fatty acid (g) & 1.5 & 14 & 1.0 & 4 \\
Omega-3 fatty acid (g) & 0.6 & 47 & 0.1 & 2 \\
Saturated fatty acids (g) & 0.8 & $*$ & 0.4 & $*$ \\
Trans fatty acids (g) & 0.3 & 4 & 0.2 & 2 \\
Fiber (g) & 1 & 7 & 0.6 & 6 \\
Sodium (mg) & 159 & 152 & & 6 \\
\hline
\end{tabular}

${ }^{(1)}$ According to Resolution 360/2003, Agência Nacional de Vigilância Sanitária (2003).

*Recommended daily allowance not established.

For some organizations, it is more efficient to establish the suitable levels of consumption for the fatty acids individually than to determine the ratio among them. According to the Food and Nutrition Board of the Institute of Medicine, the recommended daily intakes for adults are 5-10\% and $0.6-1.2 \%$ of total energy intake for the omega6 and omega-3 fatty acids, respectively (DRI's, 2002). According to the International Society for the Study of Fatty Acids and Lipids (ISSFAL), 
appropriate intake of omega- 6 fatty acid for adults is $4.44 \mathrm{~g} /$ day and for omega-3 is $2.22 \mathrm{~g} /$ day (corresponding to 2 and $1 \%$ of total energy intake) (ISSFAL, 2006). WHO recommend an intake of 5$8 \%$ for omega- 6 fatty acid and $1-2 \%$ for omega-3 in relation to daily energy consumption (Srinivasan et al., 2006). Therefore, if the means of the percentage recommendations are used $(5 \%$ for omega- 6 fatty acid and $1 \%$ for omega- 3 fatty acid), 15 slices of flaxseed bread or 23 slices of quinoa bread would need to be eaten to achieve $100 \%$ of the daily allowance for omega- 6 fatty acid, (Table 3). For omega-3 fatty acid, it was found that 7 slices of flaxseed bread or 55 slices of quinoa bread would need to be consumed.

With regard to protein content (Table 2) and its recommended daily allowance (Table 3 ), neither of the breads provided a sufficient amount to have the label of "protein-rich", which is used for the products that contribute $10 \%$ of the recommended daily intake of protein per $100 \mathrm{~g}$ of solid food (Brasil, 1998).

The two types of bread showed the same firmness. With regard to color, small differences were observed: the quinoa bread was lighter (both crust and crumb) and the bread crumb was more yellow than the flaxseed bread (Table 4).

Table 4 - Parameters of texture and the color of the crust and the crumb part of flaxseed and quinoa bread.

\begin{tabular}{lccccccc}
\hline \multirow{2}{*}{ Type of bread } & \multicolumn{3}{c}{ Crust } & \multicolumn{3}{c}{ Interior } & \multirow{2}{*}{ Firmness (N) } \\
\cline { 2 - 6 } & $\left(\mathbf{L}^{*}\right)$ & $\left(\mathbf{a}^{*}\right)$ & $\left(\mathbf{b}^{*}\right)$ & $\left(\mathbf{L}^{*}\right)$ & $\left(\mathbf{a}^{*}\right)$ & $\left(\mathbf{b}^{*}\right)$ & $2.6 \pm 0.2^{\mathrm{a}}$ \\
\hline Flaxseed bread & $60 \pm 3^{\mathrm{b}}$ & $8 \pm 2^{\mathrm{a}}$ & $22 \pm 4^{\mathrm{a}}$ & $60 \pm 2^{\mathrm{b}}$ & $4 \pm 1^{\mathrm{a}}$ & $13 \pm 1^{\mathrm{b}}$ & $3 \pm 0.1^{\mathrm{a}}$ \\
Quinoa bread & $65 \pm 4^{\mathrm{a}}$ & $7 \pm 2^{\mathrm{a}}$ & $23 \pm 3^{\mathrm{a}}$ & $66 \pm 2^{\mathrm{a}}$ & $3 \pm 0^{\mathrm{b}}$ & $15 \pm 0^{\mathrm{a}}$ & 3 \\
\hline
\end{tabular}

The same letters in the same column indicate that there was no significant difference between the samples $(\mathrm{p} \leq 0.05)$. $\mathrm{L}^{*}=$ Lightness $\left(0=\right.$ black; $100=$ white); $a^{*}=$ red-green component; $b^{*}=$ yellow-blue component.

The quinoa bread was well accepted, with a overall linking score of 5.8 (in a scale of 7), and showed a good commercial potential among the consumers of bread with functional properties, since $85 \%$ of those interviewed affirming that they would buy the product and stating that they liked the bread taste and the benefits to their health.

The results showed the possibility of development of one nutritionally safe product with sensory acceptance. The study on new forms of quinoa presentation, such as flour and meal, as well as the association of quinoa and flaxseed in the same product, could enable the development of a range of functional products.

\section{CONCLUSION}

The two products appeared suitable due to their good balances in the ratios between the polyunsaturated and saturated fatty acid concentrations and low levels of trans fatty acids. The flaxseed bread had higher levels of polyunsaturated, monounsaturated, omega- 6 and omega-3 fatty acids, as well as a more balanced omega-6/omega-3 ratio. The quinoa bread, in turn, had the advantage of significantly lower quantities of saturated fatty acid. Considering that flaxseed bread could be regarded as a standard being already consumed, the quinoa bread had very similar characteristics of color and texture. It was also well accepted by the customers, who in general stated a strong intention to buy it.

\section{RESUMO}

Grãos de linhaça e quinoa podem oferecer constituintes com efeitos fisiológicos, como os ácidos graxos (ômega-3 e ômega-6), que são importantes na prevenção de algumas doenças. $\mathrm{O}$ objetivo deste trabalho foi comparar as propriedades físico-químicas dos pães de quinoa e de linhaça. Foram também avaliados a aceitação sensorial, cor e textura. Os dois produtos se destacaram pelo adequado balanço na razão entre concentração de ácidos graxos poliinsaturados pelos saturados e baixos níveis de ácidos graxos trans. O pão de linhaça apresentou maior teor de ácidos graxos poliinsaturados, ômega- 6 e ômega3 , bem como razão ômega-6/ômega 3 mais balanceada. O pão de quinoa, por sua vez, ofereceu como vantagens quantidades menores de ácidos graxos saturados. Com relação a cor e textura, verificou-se que o pão de quinoa tinha características semelhantes ao de linhaça. O pão de quinoa apresentou ainda boa aceitação sensorial e elevada intenção de compra pelos consumidores. 


\section{REFERENCES}

ABI American Institute of Baking. (2008), AIB Standard Procedure White Pan Bread Firmness Measurement. Website: https://www.aibonline.org/ researchandtechnical/services/prodqualityeval/AIB TextureAnalysis\%20Procedures.pdf, assessed on 04.08.2008.

Bligh, E. G. and Dyer, W. J. (1959), A rapid method of total lipid extraction and purification. Canadian Journal of Biochemistry and Physiology, 37, 911917.

Brasil (1998), Portaria MS no. 27 de 13 de janeiro de 1998. Website: http://e-legis.anvisa.gov.br/ leisref/public/showAct.php?id=97, assessed on 04.08.2008.

Brasil (2003), Resolução RDC n 360, de 23 de dezembro de 2003. Website: <http://elegis.anvisa.gov.br/leisref/public/showAct.php?id=90 59>, assessed on 04.08.2008.

Choo, W-S; Birch, J. and Dufour, J-P. (2007), Physicochemical and quality characteristics of coldpressed flaxseed oils. Journal of Food Composition and Analysis, 20, 202-211

Cunnane, S. C., Ganguli, S., Menard, C., Liede, A. C., Hamadeh, M. J., Chen, Z-Y., Wolever, T. M. S. and Jenkins, D. J. A. (1993), High-linolenic acid flaxseed (Linum usitatissimum): some nutritional properties in humans. British Journal of Nutrition, 69, 443-453.

Cunniff, P.A. (1998), Official Methods of Analysis of AOAC International. 16th edition, Association of Official Analytical Chemists, Arlington.

Department of Health, 1994. Report on health and social subjects, Nutritional aspects of cardiovascular disease. Her Majesty's Stationery Office (HMSO), London.

DRI's (2002), Dietary reference intakes for energy and macronutrients. Institute of Medicine (IOM). National Academy Press, Washington.

Hall III, C. A., Manthey, F. A., Lee, R. E. and Niehaus, M. (2005), Stability of $\alpha$-linolenic acid and secoisolariciresinol diglucoside in flaxseed-fortified macaroni. Journal of Food Science and Technology, 70, 483-489.

Instituto Adolf Lutz (2005), Normas analíticas do Instituto Adolfo Lutz: Métodos químicos e físicos para análise de alimentos. 4th edition, p 1018. M.S., São Paulo.
ISSFAL (2006), International Society for the Study of Fatty Acids and Lipids. Website: http://www.issfal.org.uk, assessed on 04.08.2008.

Jump, D. B. (2002), The biochemistry of n-3 polyunsaturayed fatty acids. Journal of Biology and Chemistry, 277, 8755-8758.

Kris-Etherton, P. M., Harris, W. S. and Appel, L. J. (2002), Fish consumption, fish oil, omega-3 fatty acids, and cardiovascular disease. Circulation, 106, 2747-2757.

Kucuk, O. (2002), New opportunities in chemoprevention. Cancer Investigation, 20, 237-245.

Martin, C. A., Carapelli, R., Visentainer, J. V., Oliveira, C. C., Matsushita, M. and Souza, N. E. (2005), Trans fatty acid content of Brazilian biscuits. Food Chemistry, 93, 445-448.

Ng, S-C, Anderson, A., Coker, J. and Ondrus, M. (2007), Characterization of lipid oxidation products in quinoa (Chenopodium quinoa). Food Chemistry, 101, 185-192.

Park, S. H., Maeda, T. and Morita, N. (2005), Effect of whole quinoa flours and lipase on the chemical, rheological and breadmaking characteristics of wheat flour. Journal of Applied Glycoscience, 52, 337-343.

Sanches, S., Visentainer, J. V., Matsushita, M., Souza, N. E. (1997), Fatty Acids in Eight Varieties of Canola Brassica Napus L. Recommended for Cultivation in Paraná State, Brazil. Brazilian Archives of Biology and Technology, 40, 512-517.

Soccol, M. C. H. and Oetterer, M. (2003). Seafood as functional food. Brazilian Archives of Biology and Technology, 46, 443-454.

Spehar, C. R. and Santos, R. L. B. (2002), Quinoa BRS Piabiru: Alternativa para diversificar os sistemas de produção de grãos. Pesquisa Agropecuária Brasileira, 37, 889-893.

Srinivasan, C. S., Xavier, I. and Shankar, B. (2006), An assessment of the potential consumption impacts of WHO dietary norms in OECD countries. Food Policy, 31, 53-77. 